\title{
ON THE METAMORPHIC ORIGIN OF CERTAIN GRANITES, \&C.
} To the Editor of the Geological Magazine.

Dear Sir,-Will you kindly indulge me with space for a few words in reply to Mr. D. Forbes' letter in the last number of the Magazine.

The position which I have all along taken up, and from which I do not in the smallest degree recede, is, that the field-geologist is capable of affording valuable assistance towards the elucidation of metamorphic phenomena. To show this was the main object of my papers. My arguments were founded upon certain geological evidence which, however objectionable and unsatisfactory to $\mathbf{M r}$. D. Forbes, was, nevertheless, not of my own ereating, but may be seen by any one who shall take the trouble to examine in detail the regions described by me.

With regard to the petrological terms employed, I can only say that I never made any pretensions to be a reformer of our nomenclature, and Mr. D. Forbes' rather warm invectives might therefore have been spared. The looseness of our terminology is to be regretted, but I have only used the terms in the sense in which they have been for many years understood by British geologists. ${ }^{1}$ I shall have no cause to regret this correspondence however, if he who knows so much about the subject, and who finds that even Phillips, Lyell, and Dana are, or ought to be, ready to confess their errors, will

I Mr. D. Forbes takes me to task about my definition of greywacké as applied in a general way to the great mass of the Silurian rocks of southern Scotland, and twits me with the fact that Jameson and Macculloch understood by the term "greywacké" a definite rock-species. But however definite an idea might attach to "greywacke" some fifty or sixty years ago, that term ceased ere long to have any such precise meaning, and came to be applied to the whole series of strata in our southern uplands, formerly known as the "Transition-rocks." "There was a barbarous word," says Mr. Jukes, (Manual p. 431,) "once in use as a kind of synonym of the term "tran.sition,' this was 'grauwacké,' a word now altogether discarded, even in a lithological sense. It was one of those words that meant anything or nothing, and served merely to conceal our ignorance of the true history of the rocks to which it was applied." My critic " expected to have been referred to works specially devoted to the subject" of petrology, but the reader will see that the terms complained of were purposely used in the vague and general way in which they are commonly understood. It was, therefore, quite unnecessary that I should make allusions to those authors whose names Mr. D. Forbes su abundantly scatters through the pages of the Magazine. I may just add, that my excuse for using the word greywacke at all, was the want of some convenient general term which should not mean more than words like "Sandstone," "shale," etc. Some such term is necessary. Recurring for a moment to another of my critic's complaints, the reader may be amused when he finds $\mathrm{Mr}$. $\mathrm{D}$. Forbes admitting that, if instead of the word "certain," I had used " possible or even probable," he would not have objected to the paragraph where I speak of the metamorphism of aqueous strata into erystalline rocks, like granite, diorite, hyperite, etc. Now I have already quoted (p. 181) the statement of one of our most eminent authorities upon this subject, Dr. Sterry Hunt. That gentleman has remarked of certain crystalline rocks that they " have by most geologists been regarded as rocks of igneous origin, whereas they appear to be for the greater part undoubtedly altered sedimentary layers or masses." Dr. Sterry Hunt, it must be supposed, is well acquainted with all that has been done in this department of science, and since he thinks the use of the word "undoubtedly" quite justifiable, I cannot see why the word "certain" should require to be so loudly protested against. 
no longer retain locked up in his own mind such an invaluable store of knowledge, but will forthwith hasten to render it available for the edification of the geological world.

I am, dear Sir, faithfully yours,

KILMARNock, 13th May, 1867.

JAS. GeIKIR.

\section{MISCEIIAINEOUS.}

On the "Ocoluston" of Hydrogen by Meteoric Iron.

Ax a meeting of the Royal Society, held on Thursday, May 16th, Thomas Graham, Esq., F.R.S., F.G.S., read a paper, the subject of which was suggested by a previous one communicated to the Society in June last." The author has now examined the "natural gases" of meteoric iron. The Lenarto iron, when distilled in vacuo (by means of Sprengel's Mercurial Exhauster), gave 2.8 times its volume of gas-85 per cent. of which was pure hydrogen. It is evident that the iron must have "occluded" its hydrogen from a similar atmosphere to that proved by Messrs. Huggins and Miller to surround many of the fixed stars, of which Alpha Lyræ is the type. The discovery is a remarkable confirmation of the results of Spectrum analysis.-W.C.R.

\section{OBITUARY.}

Dr. JAMES BLACK.-We regret to have observed the notice of the decease of Dr. James Black, an old geologist, at Edinburgh, on April 30th last. at the advanced age of 79. He formerly resided at Bolton-le-Moors and Manchester, where he was widely known and generally esteemed. He was a graduate of the University of Glasgow, and Fellow of the College of Physicians of London, and actively engaged in scientific pursuits, in addition to his profession, but chiefly devoted himself to Geology and Antiquities. He joined the British Association for the Advancement of Science at its commencement in 1831, and had the honour of being elected a Fellow of the Geological Society of London in 1838, and that of France in 1848. When residing in Manchester he belonged to its Geological Society, and took an active part in its proceedings, both as member and office bearer, and also to the Philosophical Society of that city. He contributed numerous papers to each, those to the latter being chiefly archæological, and among those to the former may be mentioned-" On the Object and Uses of Geological Research," in 1841; "View of the Geology of the Isle of Arran," 1846; "Eclectic View of Coal Formations," 1847 ; "Submerged Forests of Great Britain," 1843 ; "On the Diluvium of Bolton," 1845 ; "On the Elevation and Depression of the Crust of the Earth," 1851. He was an assiduous collector of rock and fossil specimens from South Lancashire, and presented a large number to public museums, besides keeping up a considerable private collection.-J.W.B.

1 On the absorption and dialytic separation of gases by colloid septa. 